\title{
Preservation Strategy of Putar-miring Technique for Women (Case Study: Sentra Gerabah Pagerjurang, Klaten, Central Java)
}

\author{
Reza Aulia Akbar ${ }^{1}$, Faizal Putra Budimas ${ }^{1}$, Sangki Purabaya ${ }^{1}$ and Lantip Trisunarno ${ }^{1}$
}

\begin{abstract}
Sentra Gerabah Pagerjurang is one of the tourism villages in Klaten, which is known for the existence of pottery production using putar-miring techniques and craftswomen culture. The historical of putar-miring techniques and craftswomen make traditional pottery products are unique and high value to market, so that economic income and community welfare have increased. However, it was found that $73 \%$ of craftswomen didn't realize that the historical values had a significant impact on people's welfare. Therefore, if people's economic income decreases, culture existence will disappear. This research aims to formulate historical and cultural preservation strategies for putar-miring techniques and craftswomen. This research is a type of qualitative research conducted by in-depth interview, determining variables using Content Analysis, formulating strategies with SWOT analysis based on $5 M+1 E$ aspect, Community Total Led Sanitation (CLTS), as well as selecting the best preservation strategies using the Multi-Criteria-Decision-Making method. Based on this research, it can be concluded that there are six preservation strategies ranking through putar-miring techniques for women, namely: 1) Utilization of government land grants, 2) Giving historical education, culture, and economics of putar- miring technique, 3) Center of pottery developments as a tourism village, 4) Pottery production system developments, 5) Craftsmen and craftswomen training, and 6) Advocacy and negotiation government regulations.
\end{abstract}

Keywords-Community Total Led Sanitation (CLTS), Multi Criteria Decision Making (MCDM), Preservation Strategy, Putar- miring Techniques, SWOT Analysis, Traditional Pottery, and Craftswomen.

\section{INTRODUCTION}

Bayat, which is one of the sub-districts in Klaten Regency, Central Java, is an area where the majority of the population work as traditional pottery craftswomen. The method of making pottery used is a manual swivel technique that uses the foot as a driving force. Flat swivel techniques commonly used make ergonomically only men can do it. Until 1700, Sunan Bayat (Sunan Pandanaran) introduced a putar-miring technique on pottery production,

\footnotetext{
${ }^{1}$ Reza Aulia Akbar, Faizal Putra Budimas, Sangki Purabaya and Lantip Trisunarno are with Department of Industrial Engineering, Institut Teknologi Sepuluh Nopember, Surabaya, 60111, Indonesia. E-mail: reza.aulia.akbar.97@gmail.com; sangki.p@hotmail.com.
}

adapted to the conditions of women so that they could be involved in making it [1].

Until 2019, Sentra Gerabah Pagerjurang, Bayat, Klaten has 270 families with $93.3 \%$ of women as primary pottery producers, while $83.3 \%$ of men as supporting craftswomen for the pottery production process (Based on Survey Results on May 28, 2019). According to Sukanta [2] as the community leader said a minimum of $60 \%$ of the pottery production process using putar-miring techniques was carried out by women because the technique requires instincts and softness to produce some products with a thickness up to 3 millimeters. Therefore, craftsmen act as supporters to take clay and prepare a furnace. Based on this statement, it is evident that women have a dominant role in the pottery production system compared to men in producing pottery putar-miring techniques. If there are orders for putar-miring pottery products from consumers in large quantities, only women can be relied on as the main producers to complete all of these orders. This condition creates a stigma because actually women play the main role as the head of the family to support their economy and wealth.

On the other hand, there were $70 \%$ of 20 respondents (external parties) consisting of government, hotels, and business people who choose bought putar-miring products because of the reason of the cultural and historical value (putar-miring and craftswomen). This condition makes the economic income of $70 \%$ of craftswomen in the Sentra Industri Gerabah Pagerjurang more than Rp. 5,000,000 per month. However, based on the survey results, $87 \%$ of craftsmen and craftswomen did not know the history of putar-miring techniques and their influence on the value of pottery products which had been considered capable of attracting the market (demand). It can be concluded that craftsmen and craftswomen only carry out hereditary traditions because it is considered that this profession is promising economically, not the awareness to preserve culture. If the craftswomen's economy decreases significantly (the number of orders is low), so it is possible for there to look for other professions that are more economically promising. These conditions can lead to the existence of the putar-miring technique (the only one in the world) and female craftswomen extinct. 
Many training programs were included in the development of pottery production techniques carried out by external parties but were rejected by the local community because they were considered irrelevant and less needed. In fact, there is an innovation tool or technology from external parties that will replace the existence of putar-miring techniques. Not only that, until now they don't have any strategic planning and implementation of programs related to cultural preservation in the area. This condition makes the strategy and program activities can be said to be unreasonable.

This research aims to: 1) Understand the reasons for the group of productive women as the main actors in traditional pottery production at Sentra Gerabah Pagerjurang, Bayat, Klaten, Central Java, 2) Find out the strategy of changing people's stigma related to preservation of putar-miring technique at Sentra Gerabah Pagerjurang makes more sense.

This research was conducted at Sentra Gerabah Pagerjurang, Bayat, Klaten, Central Java. Bayat is one of the sub-districts in Klaten Regency, located $7 \mathrm{~km}$ southeast of Klaten City. Based on Badan Pusat Statistika (BPS) Klaten Regency data in 2018 [3], Bayat had a population of 53,434 people out of a total of $1,158,795$ people in Klaten Regency. More specifically, the population of males is 26,075 people and the female population is 27,359 with a population density of 1,767 people $/ \mathrm{km}^{2}$ [3] .

TABLE 1.

\begin{tabular}{rlc}
\multicolumn{2}{c}{ NuMBER OF FAMILY AT SENTRA GERABAH PAGERJURANG } \\
\hline \hline No & \multicolumn{1}{c}{ Wilayah } & Number of Family \\
\hline 1 & Pagerjurang Village (Center) & 208 \\
2 & Bayat Village & 1 \\
3 & Sumber Village & 8 \\
4 & Melikan Village & 9 \\
5 & Bogor Village & 15 \\
\hline \hline
\end{tabular}

Bayat sub-district consists of 6 villages which are included in traditional pottery centers, namely Pagerjurang Village, Bayat Village, Sumber Village, Melikan Village, Bogor Village, and Bantengan Village. Most of the people at Sentra Gerabah Pagerjurang work as craftswomen. Based on data from Melikan Village Secretary in 2019 (table 1), there are 208 number of family in Pagerjurang Village with details of 375 people (203 craftsmen and 172 craftswomen), while 62 families in Bayat Village, Sumber Village, Melikan Village, Desa Bogor, and Bantengan Village, there are 214 people (62 craftsmen, 42 craftswomen). Especially craftswomen, the traditional pottery produced by putar-miring technique.

Putar-miring technique is a technique using a tool in the form of circle wood, a piece of rope, and bamboo poles as supports, which are arranged in such a way that can be used by craftswomen while still observing ethical manners. The wood is rotated using the foot with a pedal system to make symmetrical and cylindrical pottery product. The slope of this rotary technique is 40 degrees -45 degrees. The putar-miring position of the pottery is directed towards the craftswomen because it makes easier for craftswomen to adjust the shape of the pottery that they want. Based on the preliminary observations (May 28, 2019), the putarmiring technique is being able to produce pottery for approximately 30 seconds for one pottery product.

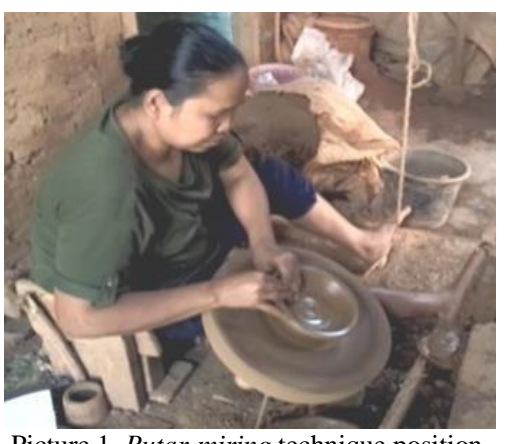

Picture 1. Putar-miring technique position.

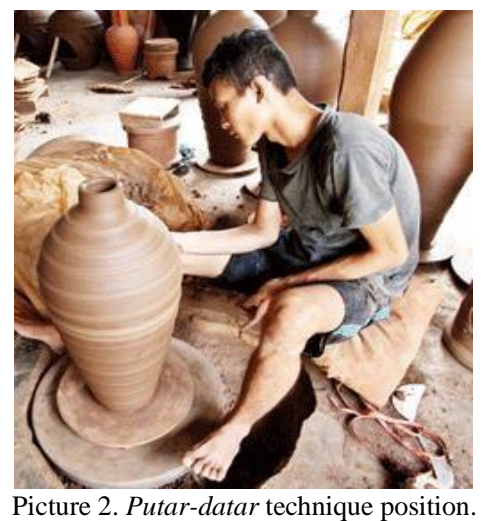

The working system of the putar-miring technique is the foot of the craftswomen is pressing the bamboo pedal which will cause the bamboo pheasant to rotate the circle wood. If the craftswomen increasingly press and pull the bamboo pedal, the circle wood will rotate. Then, if the craftswomen stop pressing and pulling on the pedal, the circle wood will stop. The putar-miring technique is analogous to the technique of pedaling a bicycle. The freewheel is a situation where craftswomen pressing pedals and fixed wheels are situations where craftsmen stop pedaling a bicycle [1].

On the other hand, in formulating a strategy for preservation of putar-miring techniques and craftswomen, there were 3 (three) stages of method and analysis, namely SWOT analysis (Strength, Weakness, Opportunity, Threat), CLTS (Community Led Total Sanitation), and MultiCriteria Decision Making (MCDM). SWOT analysis is a strategic planning technique to identify the condition of an object and formulate strategies based on the results of the analysis. According to Ferrel and Harline [4], the function of SWOT Analysis is to obtain information from the analysis of conditions and to separate them from internal issues (strengths and weaknesses) and external issues 
(opportunities and threats). The SWOT analysis can be used in a variety of ways to improve analysis in strategy setting efforts. The SWOT matrix in this research was used as a foundation in identifying internal and external conditions and strategy formulation for the Sentra Industri Gerabah Pagerjurang, Bayat, Klaten, Central Java.

CLTS (Community Led Total Sanitation) is an integrated sanitation promotion approach that aims to achieve and to maintain the culture of ODF (Open Defecation Free) or Defecation free status in the waters around the community [5]. This approach was developed by a specialist in agriculture and human resources, namely Dr. Kamal Kar who is from Sri Lanka. CLTS focuses on changing the behavior of community sanitation and sustainable development to avoid the risk of disease in the community due to dirty waters caused by the community itself.

\section{METHOD}

\section{A. Research Flowchart}

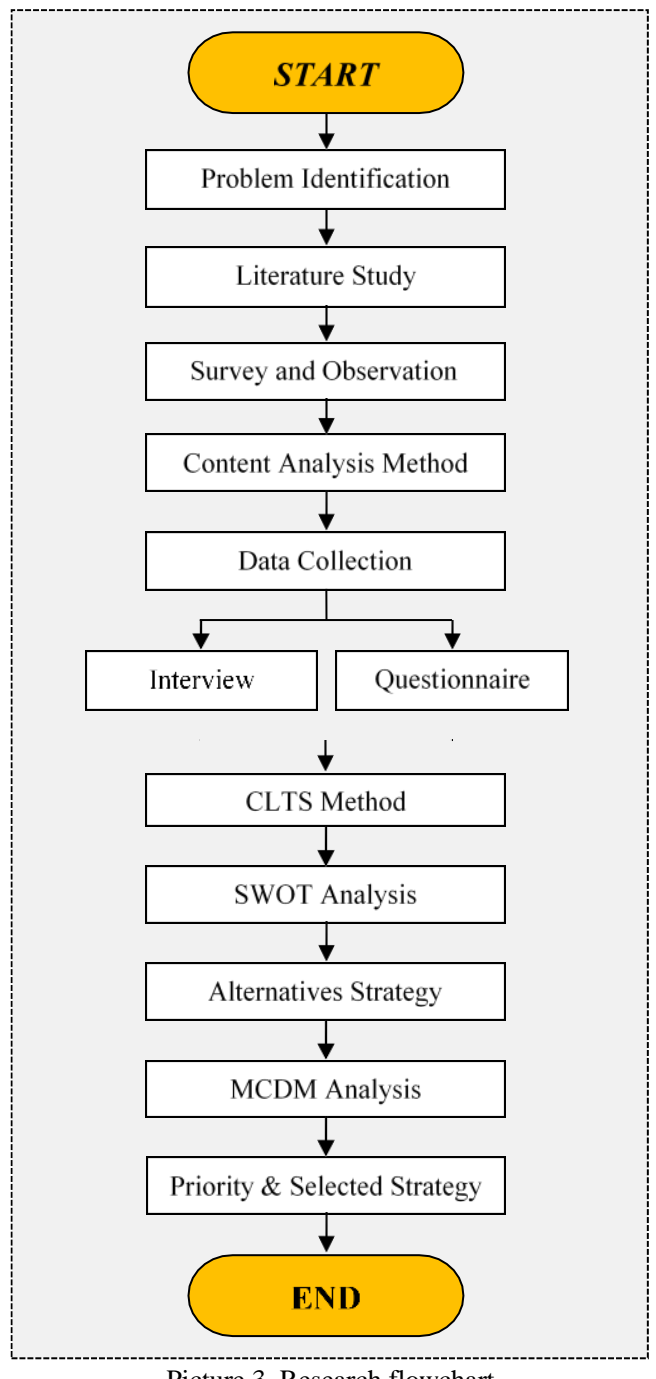

Picture 3. Research flowchart

\section{B. Data Collection Method}

Data collection in this research was conducted qualitatively using the method of literature (historical), face-to-face interviews, and structured questions (questionnaires).

1) Interview

The author conducted in-depth interviews with 30 (thirty) respondents consisting of craftsmen and craftswomen to uncover the facts of local culture, people's perceptions, and the inheritance of putar- miring techniques in the Sentra Gerabah Pagerjurang.

2) Questionnaire

The questionnaire was used to collect data related to the level of education, economics, and profession of the community in the Sentra Gerabah Pagerjurang.

3) Community's Leader

In exposing myths, culture, traditions, and history related to putar-miring techniques in the Sentra Industri Gerabah Pagerjurang, the researcher conducted in-depth interviews with stakeholders and the community's leader.

\section{Stages of Analysis}

The initial step carried out in this research was data collection using probing and mapping analysis using the SWOT Matrix method (Strength, Weakness, Opportunity, Threats). The next step is the process of implementing improvement values at the community level using the adoption of the CLTS (Community Led Total Sanitation) method.

1) SWOT Matrix

In this research, an analysis was carried out with the SWOT method on people's perceptions, culture, an inheritance of putar-miring techniques, work experience, market potential, and natural resources. The output of the mapping using the SWOT Matrix analysis is used to formulate the alternative strategy of putar-miring preservation based on actual conditions.

2) CLTS (Community Led Total Sanitation) Method

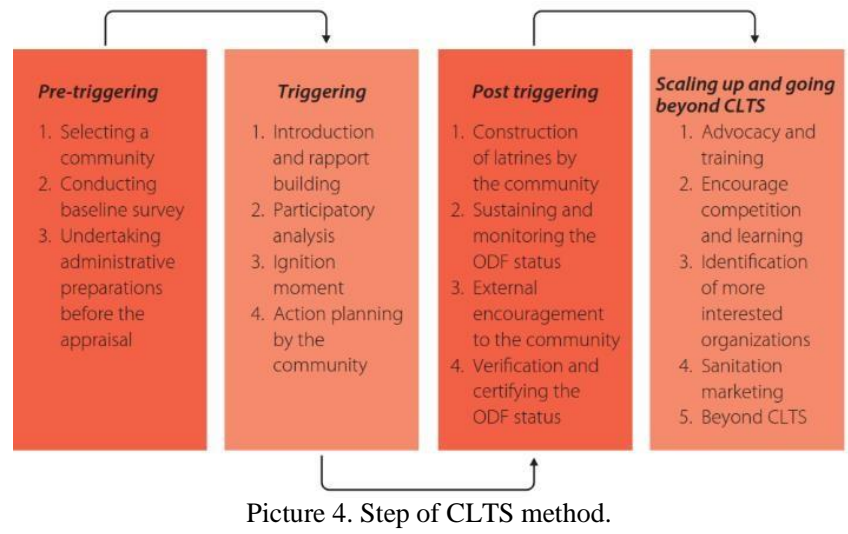

The implementation of the change strategy that has been formulated refers to the CLTS (Community Led Total Sanitation) method. This method is adopted for 
empowerment in changing the behavior of society as a whole at the community level. The stages of analysis based on the CLTS method begin with Pre-Triggering which includes a review of the community and followed by triggers to determine the trigger factors for the problem. The next step is Post- Triggering to solve problems by paying attention to local culture. Finally, making the community become accustomed to a new and relevant culture (scaling up and going beyond).

\section{3) Participatory Method}

In supporting the implementation of the CLTS concept, researchers used participatory methods in the form of group discussions or Focus Group Discussions (FGD) involving all communities in the Sentra Gerabah Pagerjurang, Bayat, Klaten, Central Java. Through this method, researchers can find out people's perceptions of local culture and the role of women in the household.

\section{Craftswomen and Craftsmen Education in Sentra Industri Gerabah Pagerjurang}

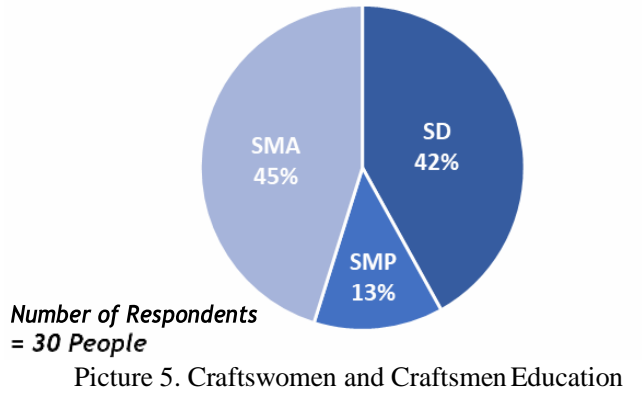

Income per Month for Craftswomen and Craftsmen in Sentra Gerabah Pagerjurang

$=<\operatorname{Rp} 3.000 .000=\operatorname{Rp} 3.000 .000-\operatorname{Rp} 5.000 .000=>\operatorname{Rp} 5.000 .000$

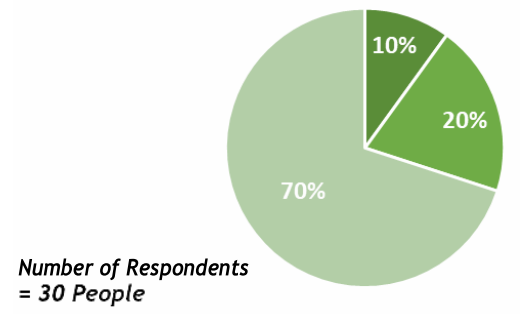

Picture 6. Income for Craftswomen and Craftsmen.

\section{Do You Support Your Children to Continue Business as Craftswomen?}

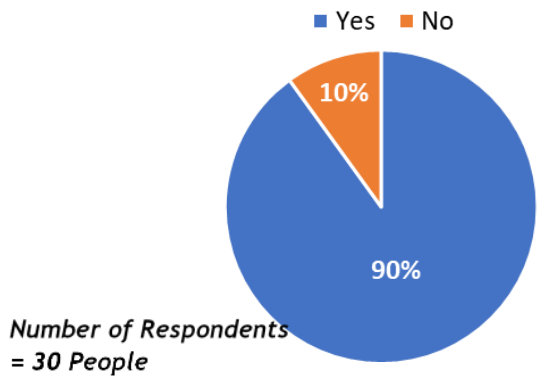

Picture 7. Craftswomen and craftsman support for business regeneration

\section{Do You Know The History of Putar- Miring Technique?}

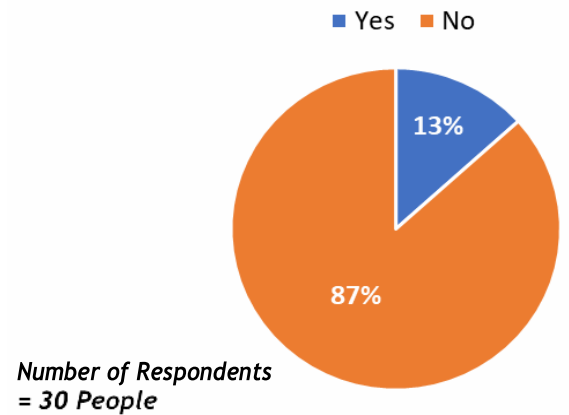

\section{RESULTS ANDDISCUSSION}

A. The Reasons for The Group of Productive Women as The Main Actors in Traditional Pottery Production at Sentra Gerabah Pagerjurang, Bayat, Klaten, Central Java

The reason for putar-miring techniques for craftswomen is related to ancient history and culture when Sunan Bayat in 1700 introduced this technique because of the women is used traditional clothes (kebaya and jarik). Therefore, the design of the putar-miring technique upholds the value of politeness and aesthetics also ergonomics for craftswomen. Ergonomics aspect is the comfort of craftswomen when making pottery with the position of the legs straight and tilted. Furthermore, according to Sukanta [2] as the leader of Melikan Tourism Village said that the reason for putarmiring techniques was only operated by women because instincts and feelings were needed when making traditional pottery using this technique. Instincts and feelings are needed when setting the thinness of the product which reaches $3 \mathrm{~mm}$ also needed when lifting these traditional pottery products. In addition, making pottery with putarmiring technique requires synchronization between hand and foot movements.

The researcher has conducted a survey of 30 respondents (external parties) consisting of government, hotels and business people. It was found that $73 \%$ of respondents bought traditional pottery products from the Sentra Industri Gerabah Pagerjurang because the products have cultural and historical values that distinguish them from other regions, especially the putar-miring technique and craftswomen. It can prove that the putar-miring technique and women have an influence on the value of products to external parties, so that, if one of them is replaced it is actually an inappropriate decision, it will eliminate the element of cultural distinctiveness. In this regard, most of the orders from external parties are traditional pottery products made using putar-miring techniques. Thus, all orders must be completed by craftswomen, while craftsmen play the role of supporting the production process (drying the pottery, preparing the furnace, and burning pottery). 
Based on the survey, the education level of craftswomen in the Sentra Gerabah Pagerjurang is 45\%of high school graduates (SMA), $13 \%$ of junior high school graduates (SMP), and $42 \%$ of elementary school graduates (SD) (picture 5). The low quality of education is the main reason people choose to work as traditional pottery craftswomen, because the process of making pottery with putar-miring techniques can be studied independently without need for complex knowledge. This is also supported by promising economic income, where currently $70 \%$ of craftswomen earn more than IDR 5,000,000 per month (picture 6). This factor is the reason $90 \%$ of craftswomen support their children to continue their business as traditional pottery craftswomen (picture 7), because income has been considered sufficient for everyday life. On the other hand, there is the fact that $87 \%$ of craftswomen do not know the

TABLE 2.

TARGET AND VARIABLES BASED ON CONTENT ANALYSIS

Target

\begin{tabular}{lll}
\hline \multicolumn{1}{c}{$\begin{array}{l}\text { Assessing The Potential for Conservation of Putar-miring Techniques Through Internal } \\
\text { and External Parties }\end{array}$} & $\begin{array}{c}\text { Assessing the Impact of Using Putar-miring Techniques on } \\
\text { Daily Activities }\end{array}$ \\
\hline $\begin{array}{l}\text { The number of youth who are members } \\
\text { of the organization or community }\end{array}$ & $\begin{array}{l}\text { The number of program plans and training } \\
\text { planned by external parties }\end{array}$ & $\begin{array}{l}\text { The number of positive and negative mindset of } \\
\text { craftswomen on the culture of the main role of community } \\
\text { pottery production }\end{array}$ \\
$\begin{array}{l}\text { Village facilities to extract resources, } \\
\text { production and marketing processes }\end{array}$ & $\begin{array}{l}\text { The number of visitors (local and international } \\
\text { tourist) }\end{array}$ & $\begin{array}{l}\text { Craftswomen productivity through pottery production using } \\
\text { putar-miring technique }\end{array}$ \\
$\begin{array}{l}\text { The amount of available natural } \\
\text { resources in the village }\end{array}$ & $\begin{array}{l}\text { The geographical location of Melikan Village } \\
\text { through center location }\end{array}$ & $\begin{array}{l}\text { Comparison of working hours and activities between men } \\
\text { and women in pottery production }\end{array}$ \\
$\begin{array}{l}\text { The economic conditions of } \\
\text { craftswomen }\end{array}$ & $\begin{array}{l}\text { The number of product from putar-miring } \\
\text { technique purchased by external parties per } \\
\text { month }\end{array}$ & $\begin{array}{l}\text { The number of hours provided by craftswomen to their } \\
\text { family }\end{array}$ \\
$\begin{array}{l}\text { The geographical location of the village } \\
\text { and natural resources }\end{array}$ & $\begin{array}{l}\text { The amount of cooperation that has been } \\
\text { carried out between the village and external } \\
\text { parties }\end{array}$ & $\begin{array}{l}\text { The number of awards / achievements of the } \\
\text { village in the field of cultural existence }\end{array}$ \\
$\begin{array}{l}\text { The number of craftswomen who know } \\
\text { the history of putar-miring techniques }\end{array}$ & \\
$\begin{array}{l}\text { The education level of craftswomen } \\
\text { and craftsmen }\end{array}$ & &
\end{tabular}

\section{B. The Strategy of Changing People's Stigma Related to Preservation of Putar-miring Technique at Sentra Gerabah Pagerjurang Makes More Sense}

In formulating a strategy for preservation of the culture of putar-miring techniques and the potential of tourism village, then it is needed a SWOT analysis, Community Total Led Sanitation (CLTS) to involving important community figures, comparing the results of strategies formulated by researchers and craftswomen communities, and Multi Criteria Decision Making (MCDM) to choose priority strategies as a consideration in formulating future history of putar-miring techniques and their influence on the value of pottery products (picture 8). Craftswomen carry out hereditary traditions only because it is considered that this profession is promising economically, not because of the awareness to preserve culture. Therefore, if people's economic income decreases, culture existence will disappear because craftsmen will switch professions (looking for more decent jobs). Thus, the putar-miring technique for women is a reasonable stigma, because traditional pottery products made by putar-miring techniques by craftswomen are of high value (history and culture). So that, one of them cannot be removed. The putar-miring and craftswomen techniques also need to be preserved to support a sustainable family economy and maintain traditions in the Sentra Gerabah Pagerjurang. 
The target of this research was to assess the potential for preservation of putar-miring techniques and to assess the impact of using this technique on daily activities. The first target is taken based on the results of content analysis which assesses that this putar-miring technique has become a hereditary and high-value culture. The second target is the view of craftswomen on culture, where the role of women in producing the traditional pottery product is more dominant than craftsmen. Therefore, this culture needs to be preserved and developed so that it is far more profitable for craftswomen and becomes one of Indonesia's global cultures. Based on these targets, the indicators refer to the level of internal and external readiness in carrying out the preservation of this putar-miring technique.

In assessing the level of internal there are variables that affect the indicators previously mentioned. Variables to measure the level of internal were assessed based on $5 \mathrm{M}$ aspects (Man, Machine, Material, Method, Money) and the results of content analysis. So that in these variables there are several aspects such as human resources, natural resources, economy, productivity, and facilities. Then, there are variables to measure the level of external based on the environmental aspect. The scope of this environment starts from the geographical location, the number of external programs, the number of awards, and collaboration with external parties.

In addition, the second target is determined based on the potential for the development of putar-miring techniques, so that they can be conserved and more beneficial for men and women. Based on the results of content analysis, the variables that affected the indicators ranged from the number of opinions (positive and negative) of craftswomen to role culture, the number of working hours, as well as comparisons of working hours productivity of daily male and female activities.

2) Strategy Formulation through SWOT Analysis The results of the second phase of qualitative

Data collection are input to the SWOT analysis and strategy formulation. The unit of analysis in carrying out this method of SWOT analysis is the Sentra Gerabah Pagerjurang. This unit is assessed based on $5 \mathrm{M}+1 \mathrm{E}$ aspects (Man, Machine, Material, Money, Method and Environment). In carrying out the SWOT analysis there are several steps that need to be carried out as follows.

\section{a. Input of SWOT Condition}

Qualitative data that has been obtained through in-dept interviews and questionnaires, then classified into aspects of $5 \mathrm{M}+1 \mathrm{E}$ and also divided based on each condition, namely Strengths, Weaknesses, Opportunities, and Threat). In this research, there are two input stages of SWOT conditions from the Sentra Gerabah Pagerjurang, namely from the perspective of researchers and the community.

\section{b. Strategy Formulation}

After inputting the conditions, the strategy is formulated with combination of SO (Strength-
Opportunity), ST (Strength-Threat), WO (WeaknessOpportunity), and WT (Weakness-Threat). The formulation of strategies through the SWOT method is used to facilitate decision makers to formulate the ideal strategy by utilizing positive and negative things on internal and external.

c. Alternative Strategy

Based on the results of the strategy formulation, then each strategy that has similarities is put together and summarized into an alternative strategy. This strategy will be used to determine the action program according to the needs of the community in the Sentra Gerabah Pagerjurang.

3) Community Total Led Sanitation (CLTS) Method

CLTS (Community Led Total Sanitation) was carried out with the aim of obtaining strategies for preservation of putar-miring techniques through discussions from the community itself. The CLTS implementation involved 30 men and women consisting of the management of the Pottery Industry Center, village officials, the younger generation, raw material owners, marketing experts, production experts, pottery historians, pottery experts, financial institutions, and putar-miring technique experts.

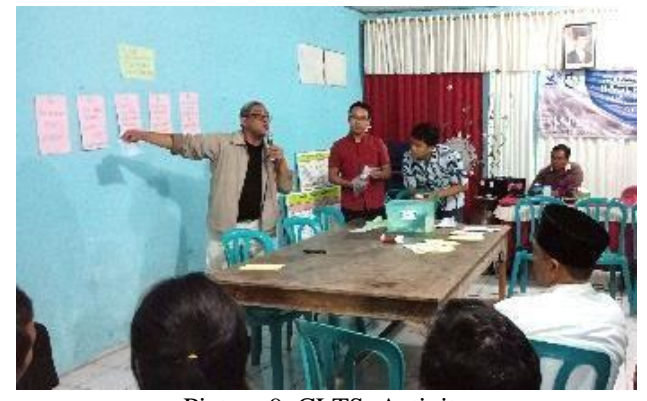

Picture 9. CLTS. Activity
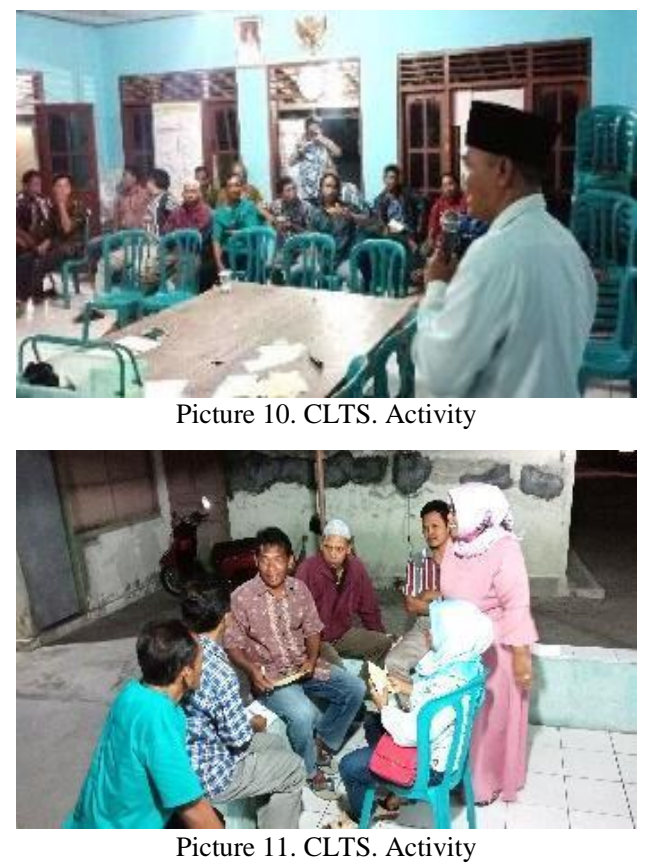


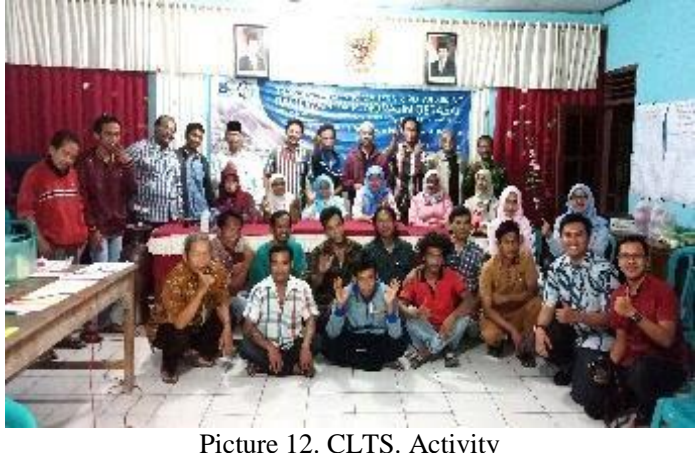

CLTS is carried out through 4 stages, where researchers as facilitators and the community as the main actors (active participation). The first stage is the community brainstorming related to putar-miring technique. This is intended to issue all kinds of ideas out of the box and experience in the process of pottery production from raw materials to be in the hands of the community. The second stage is to discuss SWOT (Strength, Weakness, Opportunity, Threat) and 30 people were divided into 4 groups. The first group discussed the strength aspect, the second group discussed the weakness aspect, the third group discussed the opportunity aspect, and the fourth group discussed the threat aspect of the putar-miring technique. The purpose of this stage is to validate the SWOT results determined by the researcher. The third stage is thinking of strategies from the SWOT results which are then compared with the strategies from the analysis results by researchers.

Based on the discussion results by the craftsmen community with considering the existing strategies, it was obtained 6 (six) alternative strategies chosen to preserve the culture of putar-miring techniques and the Sentra Gerabah Pagerjurang, namely:

a. Advocacy and negotiation government regulations

b. Utilization of government land grants

c. Pottery production system developments

d. Center of pottery developments as a tourism village

e. Craftswomen and craftsmen training

f. Giving historical education, culture, and economics of putar-miring technique

The alternative strategies produced are based on content analysis and strategy formulation with the SWOT analysis. The first strategy was taken based on community needs for government support in issuing regulations through the preservation of putar-miring techniques such as raw materials, programs, and so forth. The second strategy was chosen based on the urgency of the raw materials of the craftsmen which would run out within a period of several years. Then, the third strategy was taken based on the needs of the craftsmen to standardize the quality and price of pottery in the Sentra Gerabah Pagerjurang which was reduced. The fourth strategy is to maximize the potential for preservation of putar-miring techniques and improve the economics of craftswomen. Furthermore, the fifth strategy is to provide training in improving the quality and creativity of craftsmen (SDM). Then, the last strategy is the educate of putar miring techniques taken as fundamental in putar-miring techniques preservation. These six alternative strategies used to determine the future action plans or activities. To find out the priority strategy (ranking) of the selected strategy, a Multi-Criteria Decision Making (MCDM) analysis was carried out.

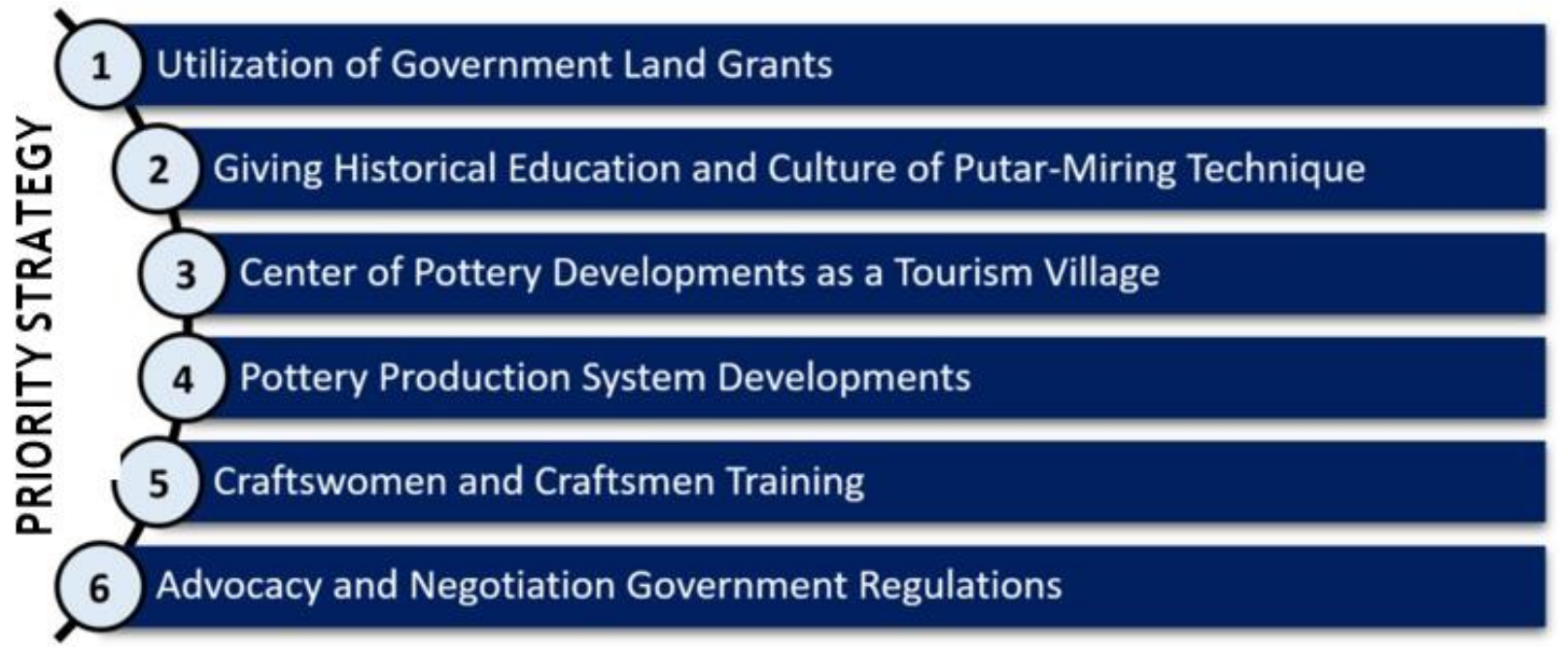

Based on the discussion results of the community of craftsmen and Melikan Tourism Village administrators by applying the Community Total Led Total Sanitation (CLTS) method

Picture 13. Selected and priority strategies based on CLTS and MCDM results 
The $1^{\text {st }}$ International Conference on Business and Management of Technology (IConBMT)

August 3rd 2019, Institut Teknologi Sepuluh Nopember, Surabaya, Indonesia

TABLE 3 .

Multi-CRiteria DeCision MAKING (MCDM) RESUlts

\begin{tabular}{|c|c|c|c|c|c|c|}
\hline \multirow{2}{*}{ No } & \multirow{2}{*}{ Alternative Strategies } & \multicolumn{3}{|c|}{ Criteria } & \multirow{2}{*}{$\mathbf{D}$} & \multirow{2}{*}{$\mathbf{E}$} \\
\hline & & $A(60 \%)$ & B $(30 \%)$ & $\mathrm{C}(\mathbf{1 0 \%})$ & & \\
\hline 1 & Advocacy and negotiation government regulations & 3 & 8 & 3 & 4,5 & 5 \\
\hline 2 & Utilization of government land grants & 10 & 10 & 3 & 9,3 & 1 \\
\hline 3 & Pottery productionsystem developments & 6 & 6 & 7 & 6,1 & 4 \\
\hline 4 & Center of pottery developments as a tourism village & 7 & 5 & 6 & 6,3 & 3 \\
\hline 5 & Craftswomen and craftsmen training & 4 & 3 & 9 & 4,2 & 6 \\
\hline 6 & Giving historical education, culture, and economics of putar- miring technique & 8 & 7 & 8 & 7,7 & 2 \\
\hline
\end{tabular}

*Information: A: Needs, B: Execution Duration, C: Craftswomen and Craftsman Capability, D: Total (Score x Criteria Weight), E: Priority (Ranking)

\section{4) MultiCriteria DecisionMaking (MCDM) Analysis}

After obtaining 6 (six) selected strategies, then carried out an analysis using the Multi-Criteria Decision Making Method (MCDM) to determine the priority strategies (ranking). Multi-criteria decision making (MCDM) is an area that is often discussed in operations research (OR). It is able to handle problems involving multiple criteria, and produce meaningful and quality decision making, especially in selecting the best alternative [6]. Based on discussions conducted by the community in the Sentra Gerabah Pagerjurang obtained three criteria, namely needs (30\%), duration of implementation (B), craftswomen and craftsmen ability (10\%). The results of the analysis using the Multi-Criteria Decision Making Method (MCDM) are in Table 3.

Table 3 shows the results of the Multi-Criteria Decision Making (MCDM) analysis are based on community assessment. Assessment and weighting have been agreed upon by all parties involved in the forum, namely craftsmen, elders, putar-miring technicians, and other parties. The rating scale (score) is $1-10$, where the higher the assessment score is the most importance strategy. Furthermore, the score is multiplied by the weight of the three predetermined criteria, namely needs (30\%), execution duration (B), craftswomen and craftsman capability (10\%).

Based on the table 3, the total score is obtained for advocacy and negotiation government regulations is $(4,5)$, utilization of government land grants is $(9,3)$, pottery production system developments is $(6,1)$, center of pottery developments as a tourism village is $(6,3)$, craftswomen and craftsmen training is $(4,2)$, and giving historical education, culture, and economics of putar-miring technique is $(7,7)$.

Based on the needs criteria, the highest score is found in the second alternative strategy, namely the utilization of government land grants because the presence of clay as a source of raw materials will soon run out. Meanwhile, the lowest score based on needs criteria is advocacy and negotiation government regulations because the government does not pay attention to the Sentra Gerabah Pagerjurang. Furthermore, the highest score for execution duration criteria is the second alternative strategy because land grants must be carried out immediately. Meanwhile, the lowest score is the fifth alternative strategy, namely craftswomen and craftsmen training because the training program has been implemented and cannot be implemented in a short time. The final criterion is craftswomen and craftsmen capability, where the highest score is found in the fifth alternative strategy because the training program can be carried out by the community itself. Meanwhile, the lowest score is the first alternative strategy because the community does not have the power regarding government policies.

Based on the three predetermined criteria (Needs, Execution Duration, Craftswomen and Craftsman Capability) and the assessment of each alternative strategy, then priority strategy ranking can be determined by multiplying the criteria weight with the score (picture 13). Based on the calculation results, the main priority strategy that must be done by craftsmen is the utilization of government land grants with a total score of 9.3. Because the urgency of the raw materials that will be used up is the main priority of the craftswomen. In addition, to providing historical, cultural and economic education, putar- miring techniques are the next priority strategy. This strategy was considered important by craftswomen, especially parents, to understand the essence of putar-miring techniques. The next strategy is followed by other total scores until the last priority strategy is a putar-miring technique training program. Basically, this strategy is one of the important strategies to do. However, when analyzed from the needs and timeframe, the craftsmen considered that this strategy was not necessary because they often did this training.

\section{CONCLUSION}

Based on this research, it can be concluded that: The putar-miring technique for women is a reasonable stigma, because traditional pottery products made by putar-miring techniques by craftswomen are of high value (history and culture). So that, one of them cannot be removed. The putar- miring and craftswomen techniques also need to be preserved to support a sustainable family economy and maintain traditions in the Sentra Gerabah Pagerjurang, 2) 
The $1^{\text {st }}$ International Conference on Business and Management of Technology (IConBMT)

August 3rd 2019, Institut Teknologi Sepuluh Nopember, Surabaya, Indonesia

There are six preservation priority strategies ranking through putar-miring techniques for women, namely: a) Utilization of government land grants, b) Giving historical education, culture, and economics of putar-miring technique, c) Center of pottery (Sentra Gerabah Pagerurang) developments as a tourism village, d) Pottery production system developments, e) Craftsmen and craftswomen training, and f) Advocacy and negotiation government regulations.

\section{RECOMMENDATION}

The recommendations from this research are as follows:

1. Application of the Community Total Led Sanitation (CLTS) Method in this study proves that the method can be used to solve community problems in the cultural and historical sectors.

2. The results of the research are expected to be a consideration for policy makers (government) in creating programs that educate the craftswomen community (Sentra Gerabah Pagerjurang)
3. The results of the reseach can be used to determine the priority of the needs of craftswomen in the Sentra Industri Gerabah Pagerjurang as a consideration in determining the conservation and potential development program of Melikan Tourism Village.

\section{REFERENCES}

[1] A. Suharson, Teknik Putar Tradisional Gerabah Proses dan Finishingnya. Yogyakarta: Arindo Offset, 2011.

[2] S. Sukanta, "Interviewee, Alasan Mengapa Teknik Putar Miring Hanya Dilakukan oleh Pengrajin Wanita di Sentra Gerabah Pagerjurang," 2019.

[3] BPS Kabupaten Klaten, "Jumlah Penduduk Menurut Kecamatan dan Jenis Kelamin di Kabupaten Klaten," 2018. [Online]. Available: https://klatenkab.bps.go.id. [Accessed: 27-Jun-2019].

[4] O. C. Ferrell and M. D. Hartline, Marketing Strategy. Mason, Ohio: Thomson/South-Western, 2005.

[5] H. K. Nabunnya and D. Nabembezi, Community Led Total Sanitation: A Handbook on Facts and Processes. Ministry of Health Uganda, 2012.

[6] N. Hafizah, H. Lamsali, and D. Sathyamoorthy, "Multi-Criteria Decision Making (MCDM) for technical evaluation of tenderers: A review of methods employed," Def. S T Tech. Bull., vol. 8, no. 1, pp. 90-102, 2015. 